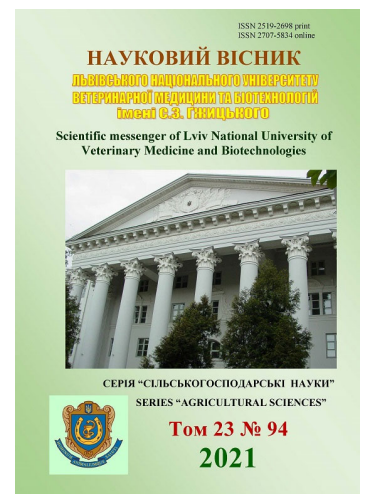

Науковий вісник Аьвівського національного університету ветеринарної медицини та біотехнодогій імені С.3. Гжицького. Серія: Сільськогосподарські науки

\section{Scientific Messenger of Lviv National University of Veterinary Medicine and Biotechnologies. Series: Agricultural sciences}

ISSN 2519-2698 print ISSN 2707-5834 online doi: 10.32718/nvlvet-a9413

https://nvlvet.com.ua/index.php/agriculture

UDC: 636:636.32:631.1.016 (477.83/87)

\title{
State and prospects of sheep breeding development in the western region of Ukraine
}

\author{
M. D. Perih, D. P. Perih, Yu. V. Kovalskyi \\ Stepan Gzhytskyi National University of Veterinary Medicine and Biotechnologies Lviv, Ukraine
}

Article info

Received 12.02.2021

Received in revised form 15.03 .2021

Accepted 16.03.2021

Stepan Gzhytskyi National University of Veterinary Medicine and Biotechnologies Lviv, Pekarska Str., 50, Lviv, 79010, Ukraine.

Tel.: +38-067-938-54-13 E-mail: prikarpatmed@ukr.net

Perih, M. D., Perih, D. P., \& Kovalskyi, Yu. V. (2021). State and prospects of sheep breeding development in the western region of Ukraine. Scientific Messenger of Lviv National University of Veterinary Medicine and Biotechnologies. Series: Agricultural sciences, 23(94), 65-72. doi: $10.32718 /$ nvlvet-a9413

Sheep farming is considered a powerful source of lamb production. The analysis of the current state of sheep breeding in the western region of Ukraine and the changes that have occurred since 1991 in this industry have been analyzed. The work was performed on the basis of generalization, analysis, synthesis and comparison of data of the State Statistics Committee for the period 1991-2019, surveys of owners of farms and farms that raise sheep, scientific publications, including online publications and web pages. The article outlines the priority areas of industry development and ways to implement them. It is noted that today sheep breeding in Ukraine is characterized by the zonal principle of placement. The main factor in this process is natural climatic and economic conditions. Analysis of statistical data shows that since 1992 the number of sheep in Ukraine, including farms of the western region, has significantly decreased, namely from 7896.2 thousand (1991) as of January 1, 2019 in all categories of farms Ukraine's sheep population decreased to 698.5 thousand or 11.3 times, and in the regions of the western region - from 848.6 thousand to 180.7 thousand or 4.7 times. It is noted that currently the bulk of the sheep population both in Ukraine and in its West (75.3 and $86.6 \%$, respectively) is concentrated in households, while at agricultural enterprises this figure is at the level of 24.7 and $13.4 \%$, respectively. The main shortcomings in the field of sheep breeding in the western region of Ukraine are reflected and possible ways to eliminate them are outlined. Sheep farms should take the following important measures: genetic improvement of meat and wool breeds and types available in the region by purebred breeding and crossing of local low-yielding uterine livestock with breeders of specialized imported meat breeds; creation of new zonal genotypes of meat and wool animals with high productive and reproductive qualities; introduction of the newest modern industrial technologies of keeping and fattening of sheep for lamb production; creation of a network of specialized slaughterhouses capable of slaughtering sheep, assessment and varietal cutting of carcasses in accordance with the requirements of international standards and specific consumers; improving the market for finished products. tion.

Key words: sheep breeding zones, sheep population, sheep productivity, wool production, lamb produc-

\section{Стан і перспективи розвитку вівчарства в західному регіоні України}

\author{
М. Д. Періг, Д. П. Періг, Ю. В. Ковальський
}

Львівський національний університет ветеринарної медицини та біотехнологій імені С. 3. Гжицького, м. Львів, Україна

Вівчарство вважається потужним джерелом виробництва ягнятини та баранини. Проведено аналіз сучасного стану вівчарства у західному регіоні України та проаналізовано зміни, які відбулися з 1991 року в даній галузі. Робота виконана на підставі узагальнення, аналізу, синтезу та порівняння даних Державного комітету статистики за період 1991-2019 років, опитувань власників селянських і фермерських господарств, які розводять овець, наукових публікаџій, у т. ч. інтернет-видань та веб-сторінок. У статті 
викладено пріоритетні напрями розвитку галузі та шляхи їх виконання. Зазначено, щзо сьогодні вівчарству в Україні характерний зональний принцип розміщення. Головним фактором цьього процесу є природно-кліматичні та господарські умови. Аналізуючи статистичні дані, виявили, щуо починаючи з 1992 року поголів'я овець в Украӥні, в тому числі в господарствах західного регіону, істотно зменшилося, а саме з 7896,2 тис. (1991 р.) станом на 1 січня 2019 року в усіх категоріях господарств Украӥни поголів'я овець зменшилося до 698,5 тис., або у 11,3 раза, а в областях західного регіону - з 848,6 тис. до 180,7 тис., або у 4,7 раза. Зазначено, щзо в даний час основна маса поголів'я овець як в Украӥні, так $і$ на ї̈ заході (75,3 $i$ 86,6 \% відповідно) зосереджена в господарствах населення, тимчасом як на сільськогосподарських підприємствах ией показник перебуває на рівні 24,7 , 13,4 \% відповідно. Відображено основні недоліки в галузі вівчарства західного регіону Украӥни та накреслено можливі шляхи їх усунення. Господарствам з розведення овець варто провести такі важливі заходи: генетичне вдосконалення наявних в регіоні м'ясо-вовнових порід і типів методом чистопородного розведення та схрещування місчевого низькопродуктивного маточного поголів'я із плідниками спеціалізованих імпортних м'ясних порід; створення нових зональних генотипів тварин м'ясо-вовнового напряму продуктивності з високими продуктивними та відтворювальними якостями; впровадження новітніх сучасних промислових технологій утримання і відгодівлі овецьь для виробництва ягнятини; створення мережі спеціалізованих забійних пунктів, здатних проводити забій овець, оцінку та сортовий розруб туш згідно з вимогами міжнародних стандартів і конкретних споживачів; поліпшення ринку збуту виробленої готової продукції.

Ключові слова: західний регіон Украйни, зони вівчарства, поголів'я овець, продуктивність овецьь, виробництво вовни, виробниитво баранини.

\section{Вступ}

Вівчарство в Україні і в західному регіоні зокрема склалося традиційно і було найважливішою галуззю громадського тваринництва. Воно забезпечувало потребу вітчизняної текстильної промисловості у вовні, смушках хутрових і кожухових овчинах та шкурах, а також постачало для населення цінні високопоживні продукти харчування, такі як м'ясо (ягнятина, баранина), жир (лій), а в окремих зонах - молоко, з якого народні сировари виготовляли висококалорійні тверді та м'які сири. Найбільше значення для народного господарства має вовна, яка завдяки цінним технічним властивостям - міцності, розтяжності, еластичності, пластичності, гігроскопічності, здатності до звалювання та ін. є найкращою сировиною для виробництва тканин, трикотажу, килимів, валяних виробів тощо. Окрім того, при додаванні до натуральної вовни відповідної кількості синтетичних або хімічних волокон поєднується ціла низка цінних якостей, властивих волокнам обох видів. Це дає змогу значно розширити асортимент тканин, таких як нейлон, орлон, капрон та інші (Sando et al., 2000; Perih et al., 2003; Sinclair, 2007; Vdovychenko \& Zharuk, 2013; Melnychuk \& Yuskiv, 2018; Havryliak et al., 2018; Tkachuk et al., 2018).

Вівчарство вважається потужним джерелом виробництва ягнятини та баранини. У вівчарстві м'ясововнового напрямку продуктивності баранина в його економіці посідає рівне місце з виробництвом вовни. Баранина вирізняється високим вмістом повноцінного білка, а також незамінних амінокислот. Цінною ознакою баранини є також невисокий вміст в жирі холестерину - 29 мг\% порівняно з воловим - 75 мг\% та свинини - 74,5 - 126 мг\%. Варто зазначити, що популярність баранини у світі постійно зростає (Sokol, 2003; Perih \& Kyryliv, 2013; Sedilo et al., 2015; Vdovychenko et al., 2019).

Як бачимо, за різноманітністю продукції вівці займають одне з провідних місць серед інших сільськогосподарських тварин. Водночас господарськокорисні якості овець (висока відтворна здатність, скороспілість, висока оплата спожитого корму, тривалість використання репродуктивного поголів'я, плодючість і багатоплідність) забезпечують перевагу їх порівняно 3 іншими видами сільськогосподарських тварин (Perih \& Kyryliv, 2013; Vdovychenko \& Zharuk, 2013).

Мета роботи - вивчити наявний стан та проаналізувати зміни, що відбулися з 1991 року в галузі вівчарства західного регіону України, охарактеризувати природно-кліматичні особливості окремих областей та їх специфіку, визначити основні проблемні питання та накреслити можливі шляхи подальшого їх вирішення.

\section{Матеріал і методи досліджень}

Робота виконана на підставі узагальнення, аналізу, синтезу та порівняння даних Державного комітету статистики за період 1991-2019 років, опитувань власників селянських і фермерських господарств, які розводять овець, наукових публікацій, у т. ч. інтернет-видань та веб-сторінок.

\section{Результати та їх обговорення}

Сьогодні вівчарству в Україні характерний зональний принцип розміщення. Головним фактором цього процесу $є$ природно-кліматичні та господарські умови. Водночас у сучасних економічних умовах одним 3 найважливіших факторів $\epsilon$ етнічний склад населення регіону та його традиції, які пов'язані 3 вівчарством. Це надзвичайно важливо в умовах нестабільності ринку, яка у деяких областях призвела до майже повної ліквідації вівчарства (Perih et al., 2003; Perih \& Kyryliv, 2013; Vdovychenko \& Zharuk, 2013; Sedilo et al., 2015).

Концентрація поголів'я по зонах залежить і від наявності важкодоступних для інших видів сільськогосподарських тварин кормових ресурсів, насамперед пасовищ. Найбільша чисельність поголів'я овець - в зонах, території яких непридатні до інтенсивного землеробства через кліматичні, рельєфні умови тощо (Vdovychenko \& Zharuk, 2013; Sedilo et al., 2015).

У західному регіоні України історично склалися три зони вівчарства: передкарпатська (Тернопільська, Рівненська, Волинська та низинні райони Львівської, Івано-Франківської та Чернівецької областей), карпатська (гірські райони Львівської, ІваноФранківської, Чернівецької та Закарпатської облас- 
тей) та закарпатська (низинні райони області). Кожна із цих зон характеризується своєю специфікою розвитку вівчарства, що обумовлено як природнокліматичними умовами його існування, так і відповідним генофондом овець (Terek et al., 2003; Perih \& Kyryliv, 2013).

Для зони Карпат характерними факторами є: поперше, наявність великих масивів гірських пасовищ, які протягом 5 місяців забезпечують овець різноманітними зеленими кормами; по-друге, попит на овечу молочну продукцію (м'які і тверді сири); по-третє, наявність народних промислів 3 переробки овечої вовни, з якої виробляють килими, ковдри, “ліжники”, шкарпетки тощо і по-четверте, розвинена санаторнокурортна туристична інфраструктура. У гірській зоні населення розводить овець української гірськокарпатської породи. Популяція овець належить до комбінованого вовново-молочно-м'ясо-овчинного виробничого напрямку продуктивності, які добре пристосовані до екстремальних умов карпатського регіону. Це єдина в Україні порода, яка продукує високоякісну килимову вовну, дає добротні кожухово-хутрові овчини і товарне молоко. Дана порода була затверджена Міністерством сільського господарства і продовольства України 30 грудня 1993 року. У породі овець виділено два внутрішньопородних типи: передкарпатський i закарпатський, які дуже мало відрізняються за тілобудовою та якістю вовни. Вівці закарпатського типу характеризуються грубішою вовною і вищим виходом чистого волокна (70 \%); в овець передкарпатського типу вовна тонша, вирізняється доброю вирівняністю за сортом як в руні, так і в косиці, вихід чистого волокна коливається в межах 65-68 \% (Petryshyn et al., 1995; Terek et al., 1999; Perih \& Kyryliv, 2013; Sedilo et al., 2015).

Для низинних районів закарпатської зони характерним є розведення скороспілих тонкорунних овець типу прекос. За своїм походженням і продуктивністю вони аналогічні угорським тонкорунним вівцям камвольним і м'ясним мериносам. Закарпатські тонкорунні вівці за ростом і величиною тіла належать до середніх і займають проміжне місце між спеціалізованими м'ясо-вовновими та вовновими породами. Сучасні закарпатські тонкорунні вівці типу прекос характеризуються добрим поєднанням вовнової і м'ясної продуктивності. Жива маса баранів - 85-100 кг, маток - 53-58 кг; настриг немитої вовни відповідно - 9,011,0 і 4,5-5,0 кг при виході чистої вовни 50-52\%. Тонина вовни переважно 64 і 60 якості, трапляються тварини із тониною вовни 70 якості (Vdovychenko \& Zharuk, 2013; Sedilo et al., 2015).

Особливу увагу привертає передкарпатська низинна зона Львівської, Івано-Франківської та Чернівецької областей, а також зона інших областей західного регіону України (Тернопільська, Рівненська, Волинська), яким притаманні вологий клімат, велика розораність земель та перевага господарств 3 розвитку молочного скотарства.

Історичні дані свідчать про те, що галузь вівчарства на цих теренах розвивалась $з$ давніх часів. Колишні вівці, яких розводили селяни цього краю, були грубововновими, ця вовна через низьку якість текстильною промисловістю не перероблялась. 3 грубої вовни селяни виготовляли переважно килимові вироби, а 3 овчин - кожухи. Вівці мали універсальний виробничий напрям продуктивності, а разом 3 тим характеризувались надмірно низькою вовновою та м'ясною продуктивністю. Так, жива маса вівцематок становила 25-35 кг, а річний настриг немитої вовни - 1,2-1,5 кг.

У зв'язку з цим після Другої світової війни і приєднання західних областей до України Міністерством сільського господарства було прийнято рішення перетворити малопродуктивне грубововнове вівчарство даного регіону на тонкорунне. Внаслідок проведеного поглинального схрещування грубововнових маток 3 баранами тонкорунної породи прекос за період 19501965 років грубововнове вівчарство було перетворено в тонкорунне. Отже, було створено новий масив тонкорунних овець - місцевих прекосів (Holovach, 1996; Perih et al., 2003).

Сьогодні в умовах ринку українського зразка, де відсутнє поняття соціальної доцільності, а є лише прибуток будь-якою ціною, галузь вівчарство, як i тваринництво взагалі, перебуває на межі не розвитку, a існування. Принагідно нагадати, що на 01 січня 1991 року поголів'я овець у господарствах усіх категорій України становило 7896,2 тисячі голів, у західному регіоні - 848,6 тисяч (10,7 \% від загального поголів'я; табл. 1). У цей період все поголів'я овець в основному зосереджувалося в сільськогосподарських підприємствах $(90,7 \%)$, тимчасом як в господарствах населення було лише 9,3\%.

Серед областей західного регіону найбільша кількість овець в цей період була зосереджена в господарствах усіх категорій Закарпатської (29,1%), Тернопільської (17,2 \%), Чернівецької (16,3 \%) і Волинської $(14,9 \%)$ областей, а найменша - в господарствах Львівської (6,0 \%), Івано-Франківської (6,5\%) та Рівненської (10\%) областей. Характеризуючи господарства населення регіону, то 3 таблиці 1 видно, що найбільше овець на початку незалежності України розводили селяни Чернівецької $(31,4$ \%) і Закарпатської $(20,3 \%)$ областей, а найменше - Тернопільської (1,6 \%), Рівненської (4,8 \%) і Волинської (9,2 \%), тимчасом як Івано-Франківська (17,3 \%) і Львівська (14,8 \%) області за даним показником займали проміжне місце. Концентрація поголів'я в господарствах населення Чернівецької, Закарпатської, ІваноФранківської і Львівської областей обумовлена наявністю важкодоступних для інших видів сільськогосподарських тварин кормових ресурсів, насамперед пасовищ. У цих областях найбільша кількість поголів'я овець зосереджувалася в гірських зонах, території яких непридатні до інтенсивного землеробства через кліматичні, рельєфні та інші умови. Так, для зони Карпат позитивним фактором є наявність великих масивів гірських пасовищ (полонин), які протягом 5 місяців забезпечують овець різноманітними зеленими кормами. 
Таблиця 1

Динаміка поголів’я овець в господарствах західного регіону України, тис. гол.

\begin{tabular}{|c|c|c|c|c|c|c|}
\hline \multirow{2}{*}{ Країна, область } & \multicolumn{5}{|c|}{ Рік } & \multirow{2}{*}{$\begin{array}{c}2019 \\
\text { в \% до } 1991\end{array}$} \\
\hline & 1991 & 2001 & 2011 & 2015 & 2019 & \\
\hline \multirow{4}{*}{ Україна } & $7896,2^{*}$ & 963,1 & 1100,5 & 785,8 & 698,5 & 8,8 \\
\hline & $7164,1 * *$ & 412,4 & 294,9 & 200,8 & 172,5 & 2,4 \\
\hline & $732,1 * * *$ & 550,7 & 805,6 & 585,0 & 526,0 & 71,8 \\
\hline & $9,3 * * * *$ & 57,1 & 73,2 & 74,4 & 75,3 & - \\
\hline \multirow{4}{*}{ Волинська } & 126,1 & 11,6 & 7,7 & 8,6 & 8,3 & 6,6 \\
\hline & 116,9 & 1,0 & 0,5 & 0,8 & 0,2 & 0,2 \\
\hline & 9,2 & 10,6 & 7,2 & 7,8 & 7,1 & 77,2 \\
\hline & 7,3 & 91,4 & 93,5 & 90,7 & 85,5 & - \\
\hline \multirow{4}{*}{ Закарпатська } & 247,7 & 73,2 & 102,5 & 114,6 & 115,2 & 46,5 \\
\hline & 197,3 & 10,6 & 17,7 & 10,7 & 7,1 & 3,6 \\
\hline & 50,4 & 62,6 & 84,8 & 103,9 & 108,1 & 214,5 \\
\hline & 20,3 & 85,5 & 82,7 & 90,7 & 93,8 & - \\
\hline \multirow{4}{*}{ Івано-Франківська } & 55,6 & 22,4 & 7,1 & 9,3 & 9,3 & 16,7 \\
\hline & 46,0 & 0,4 & 0,7 & 2,3 & 3,5 & 7,6 \\
\hline & 9,6 & 22,0 & 6,4 & 7,0 & 5,8 & 60,4 \\
\hline & 17,3 & 98,2 & 90,1 & 75,3 & 62,4 & - \\
\hline \multirow{4}{*}{ Львівська } & 50,5 & 8,2 & 5,4 & 8,7 & 8,1 & 16,0 \\
\hline & 46,0 & 0,6 & 1,5 & 3,8 & 2,8 & 6,1 \\
\hline & 7,5 & 7,6 & 3,9 & 4,9 & 5,3 & 70,7 \\
\hline & 14,8 & 92,7 & 72,2 & 56,3 & 65,4 & - \\
\hline \multirow{4}{*}{ Рівненська } & 84,6 & 5,8 & 4,8 & 5,9 & 4,3 & 5,1 \\
\hline & 80,5 & 1,0 & 1,2 & 1,6 & 0,5 & 0,6 \\
\hline & 4,1 & 4,8 & 3,6 & 4,3 & 2,6 & 63,4 \\
\hline & 4,8 & 82,7 & 75,0 & 72,9 & 60,5 & - \\
\hline \multirow{4}{*}{ Тернопільська } & 145,9 & 2,3 & 1,5 & 1,7 & 2,4 & 1,6 \\
\hline & 143,6 & 0,4 & 0,4 & 0,5 & 0,1 & 0,07 \\
\hline & 2,3 & 1,9 & 1,1 & 1,2 & 1,4 & 60,9 \\
\hline & 1,6 & 82,6 & 73,3 & 70,6 & 58,3 & - \\
\hline \multirow{4}{*}{ Чернівецька } & 138,2 & 47,0 & 39,7 & 35,8 & 33,1 & 23,9 \\
\hline & 94,8 & 9,1 & 5,9 & 5,0 & 4,4 & 4,6 \\
\hline & 43,4 & 37,9 & 33,8 & 30,8 & 28,7 & 66,1 \\
\hline & 31,4 & 80,6 & 85,1 & 86,0 & 86,7 & - \\
\hline
\end{tabular}

Проте, починаючи з 1992 року, з різних причин поголів'я овець в Україні, в тому числі в господарствах західного регіону, стрімко зменшилось, а якщо відверто, то ця галузь практично перестала існувати. Так, 3 7896,2 тис. (1991р.) станом на 1 січня 2019 року в усіх категоріях господарств України поголів'я овець зменшилося до 698,5 тис., або у 11,3 раза, а в областях західного регіону - 3 848,6 тис. до 180,7 тис., або у 4,7 раза. Таке зменшення, як вважають більшість експертів, можна пояснити тим, що в умовах планової економіки колишнього Радянського Союзу галузь вівчарства була зорієнтована переважно на виробництво вовни. На цей вид текстильної сировини були встановлені відносно високі ціни, а обсяги іiї виробництва та чисельність поголів'я овець регламентувалися жорстким регулюванням. Із 2000 року різко знизився попит на вовну та знизилися ціни на неї. Вівчарські господарства, в яких основний дохід отримували від реалізації вовни, здебільшого припинили своє існування. У регіонах, де традиційно практикувалося доїння овець (Буковина, Гуцульщина та гірські райони Закарпаття), скорочення поголів'я овець було менш істотним, порівняно 3 низинними областями західного регіону і загалом по Україні. Так, у 1991 році в чотирьох областях Західної
України (Закарпатська, Івано-Франківська, Львівська і Чернівецька) було зосереджено 58 \% від загального поголів'я регіону, а в 2019 році - 91,7 \%, у тому числі частка Закарпатської та Чернівецької областей становить 63,7 і 18,3 \% відповідно.

У даний час основна маса поголів'я овець як в Україні, так і на іiі Заході, (75,3 і 86,6 \% відповідно) зосереджена в господарствах населення, тимчасом як на сільськогосподарських підприємствах цей показник перебуває на рівні 24,7 і 13,4 \% відповідно.

Якщо шукати причини занепаду галузі, то вони $є$ різними - як об'єктивними, так і суб'єктивними, або необгрунтованими.

Першою причиною відсталості галузі є те, що незважаючи на докорінне поліпшення якості вовни, місцеві породи овець залишаються порівняно малопродуктивними (табл. 2).

3 даних таблиці 2 видно, що середній річний настриг немитої вовни на вівцю в господарствах усіх категорій України знизився з 3,4 кг (1990р.) до 2,7 кг (2018 р.). 3 семи західних областей лише в господарствах Чернівецької області селекціонери-вівцеводи домоглися збільшення даного показника продуктивності овець з 2,7 кг до 3,4 кг (табл. 3). 
Характеризуючи господарства областей західного регіону, як подано у таблиці 3, у 1990 році найбільше вовни виробляли в господарствах Закарпатської (28,2 \% від загальної кількості регіону) і Чернівецької $(17,4 \%)$ областей, а найменше - Львівської (5,2\%) та Івано-Франківської (7,0 \%), тимчасом як господарства Тернопільської (16,1%), Волинської (13,9 \%) і Рівненської (12,1%) областей за даним показником займали проміжне місце.

Другою причиною збитковості галузі були істотні недоліки в організації відтворення стада. Практикою доведено, що в товарному вівчарстві питома вага вівцематок в стаді має становити 70-80\%, а не $40 \%$, як часто буває. Таке збільшення питомої ваги в стаді вівцематок дає можливість збільшити виробництво молодої баранини на 22-24 \% за рахунок підвищення виходу ягнят.
Третьою причиною низької продуктивності овець та низької рентабельності галузі є недостатній рівень їх годівлі та утримання, зокрема в зимово-стійловий період, що гальмує прояв і розвиток генетичного потенціалу овець будь-якої породи. Особливо це стосується збалансованого протеїнового живлення.

Четвертою причиною відставання галузі є недоліки в організації та проведенні вирощування племінного молодняку.

П'ятою причиною занепаду вівчарства в господарствах регіону є погана організації збуту та переробки вівчарської продукції - вовни та овчин, що викликало таку ситуацію в господарствах та спад розвитку цієї галузі.

Отже, як вважають більшість практиківвівцеводів, це і $є$ основні істотні причини, які зумовили занепад вівчарства.

\section{Таблиця 2}

Середній річний настриг вовни з вівці в господарствах західного регіону України, кг

\begin{tabular}{|c|c|c|c|c|c|c|}
\hline \multirow[b]{2}{*}{ Країна, область } & \multicolumn{5}{|c|}{ Рік } & \multirow{2}{*}{$\begin{array}{c}2018 \\
\text { в \% до } 1990\end{array}$} \\
\hline & 1990 & 2000 & 2010 & 2015 & 2018 & \\
\hline \multirow{4}{*}{ Україна } & $3,4^{*}$ & 3,0 & 3,4 & 2,9 & 2,7 & 79,41 \\
\hline & $3,4 * *$ & 2,4 & 2,3 & 1,7 & 1,5 & 44,11 \\
\hline & $4,2 * * *$ & 3,8 & 3,8 & 3,3 & 3,0 & 71,42 \\
\hline & $123,5 * * * *$ & 126,7 & 111,8 & 113,8 & 111,1 & - \\
\hline \multirow{4}{*}{ Волинська } & 2,5 & 2,2 & 2,2 & 2,0 & 2,2 & 88,0 \\
\hline & 2,4 & 1,4 & 1,3 & 2,0 & 1,5 & 62,5 \\
\hline & 3,3 & 2,2 & 2,3 & 2,0 & 2,3 & 69,7 \\
\hline & 132,0 & 100,0 & 104,5 & 100,0 & 104,5 & - \\
\hline \multirow{4}{*}{ Закарпатська } & 2,5 & 2,3 & 2,1 & 1,6 & 1,8 & 72,0 \\
\hline & 2,5 & 1,7 & 2,4 & 2,0 & 1,6 & 64,0 \\
\hline & 2,7 & 2,5 & 2,0 & 1,6 & 1,8 & 66,7 \\
\hline & 108,0 & 108,7 & 95,2 & 100,0 & 100,0 & - \\
\hline \multirow{4}{*}{ Івано-Франківська } & 2,2 & 2,5 & 2,8 & 2,5 & 2,5 & 113,6 \\
\hline & 2,2 & 1,2 & 1,8 & 1,6 & 1,7 & 77,3 \\
\hline & 2,3 & 2,6 & 3,0 & 2,9 & 2,9 & 126,1 \\
\hline & 104,5 & 104,0 & 107,1 & 116,0 & 116,0 & - \\
\hline \multirow{4}{*}{ Львівська } & 2,1 & 2,4 & 2,1 & 2,5 & 2,2 & 104,8 \\
\hline & 2,2 & 0,8 & 1,1 & 2,5 & 1,7 & 77,3 \\
\hline & 1,8 & 2,7 & 2,5 & 2,4 & 2,5 & 138,9 \\
\hline & 85,7 & 112,5 & 119,0 & 96,0 & 113,6 & - \\
\hline \multirow{4}{*}{ Рівненська } & 2,1 & 1,8 & 3,9 & 3,4 & 2,0 & 95,2 \\
\hline & 2,1 & 1,0 & 1,7 & 0,8 & 0,7 & 33,3 \\
\hline & 1,7 & 2,0 & 4,6 & 4,4 & 2,6 & 152,9 \\
\hline & 80,9 & 111,1 & 117,9 & 129,4 & 130,0 & - \\
\hline \multirow{4}{*}{ Тернопільська } & 2,5 & 2,2 & 1,4 & 1,3 & 1,2 & 48,0 \\
\hline & 2,5 & 0,2 & - & - & - & - \\
\hline & 2,6 & 2,7 & 1,8 & 1,3 & - & - \\
\hline & 104,0 & 122,72 & 128,57 & 100,0 & - & - \\
\hline \multirow{4}{*}{ Чернівецька } & 2,7 & 3,3 & 3,3 & 3,7 & 3,6 & 133,3 \\
\hline & 2,6 & 1,8 & 2,4 & 2,2 & 2,0 & 76,9 \\
\hline & 3,0 & 3,8 & 3,4 & 3,9 & 3,8 & 126,7 \\
\hline & 111,1 & 115,1 & 103,0 & 105,4 & 105,5 & \\
\hline
\end{tabular}

Примітка: * - усі категорії господарств; ** - сільськогосподарські підприємства; *** - господарства населення; **** частка господарств населення, \%.

Як зазначають Ю. В. Вдовиченко і П. Г. Жарук (Vdovychenko \& Zharuk, 2013), умови сьогоднішнього ринку склалися таким чином, що основною умовою існування галузі $є$ виробництво м'яса. Особливим попитом користується ягнятина та молода баранина, тому цей напрям вівчарства все більше приваблює виробників у багатьох країнах світу, а відтак вони постійно вишукують ефективні шляхи його інтенсифікації. Приклад інтенсивного ведення вівчарства - у Франції, де з 8,0 млн голів овець 6,2 млн - вівцематки, у т. ч. 4,0 млн м'ясного напряму продуктивності, виробляється 111 тис. т, або 18 кг м'яса на вівцематку. У грошовому виразі це 1100-1200 грн, і при цьому надається субсидія в розмірі 16 євро на голову і 220 євро 
на 1 га сільськогосподарських угідь. На ринках ОАЕ та Саудівської Аравії ціна на морожену баранину становить 2,0-2,2 дол. США, на охолоджену - 4,0-
4,01, охолоджена баранина 3 Франції - 9,0 дол. (Vdovychenko \& Zharuk, 2013).

Таблиця 3

Виробництво вовни всіх видів в господарствах західного регіону України, тонн

\begin{tabular}{|c|c|c|c|c|c|c|}
\hline \multirow{2}{*}{ Країна, область } & \multicolumn{5}{|c|}{ Рік } & \multirow{2}{*}{$\begin{array}{c}2018 \\
\text { в \% до } 1990\end{array}$} \\
\hline & 1990 & 2000 & 2010 & 2015 & 2018 & \\
\hline \multirow{4}{*}{ Україна } & 29804* & 3400 & 4192 & 2270 & 1908 & 6,4 \\
\hline & $26466 * *$ & 1311 & 710 & 314 & 236 & 0,9 \\
\hline & $3338 * * *$ & 2089 & 3482 & 1956 & 1672 & 50,1 \\
\hline & $11,2 * * * *$ & 61,4 & 83,1 & 86,2 & 87,6 & - \\
\hline \multirow{4}{*}{ Волинська } & 327 & 30 & 20 & 18 & 19 & 5,8 \\
\hline & 303 & 2 & 1 & 2 & 2 & 0,7 \\
\hline & 24 & 28 & 19 & 16 & 17 & 70,8 \\
\hline & 7,3 & 93,3 & 95,0 & 88,9 & 89,5 & - \\
\hline \multirow{4}{*}{ Закарпатська } & 665 & 191 & 218 & 185 & 188 & 28,3 \\
\hline & 531 & 27 & 45 & 21 & 13 & 2,4 \\
\hline & 134 & 164 & 173 & 164 & 175 & 130,6 \\
\hline & 20,1 & 85,9 & 79,4 & 88,6 & 93,1 & - \\
\hline \multirow{4}{*}{ Івано-Франківська } & 166 & 56 & 19 & 23 & 22 & 13,2 \\
\hline & 142 & 1 & 1 & 3 & 5 & 3,5 \\
\hline & 24 & 55 & 18 & 20 & 17 & 70,8 \\
\hline & 14,5 & 98,2 & 94,7 & 86,9 & 77,3 & - \\
\hline \multirow{4}{*}{ Львівська } & 123 & 21 & 12 & 14 & 19 & 82,6 \\
\hline & 112 & 0 & 2 & 2 & 6 & 5,4 \\
\hline & 11 & 21 & 10 & 12 & 13 & 118,2 \\
\hline & 8,9 & 100,0 & 83,3 & 85,7 & 68,4 & - \\
\hline \multirow{4}{*}{ Рівненська } & 285 & 10 & 20 & 20 & 13 & 4,6 \\
\hline & 279 & 1 & 2 & 1 & 1 & 0,4 \\
\hline & 6 & 9 & 18 & 19 & 12 & 200,0 \\
\hline & 2,1 & 90,0 & 90,0 & 95,0 & 92,3 & - \\
\hline \multirow{4}{*}{ Тернопільська } & 379 & 6 & 2 & 2 & 3 & 0,8 \\
\hline & 378 & - & - & - & - & - \\
\hline & 1 & 6 & 2 & 2 & 3 & 300 \\
\hline & 0,3 & 100 & 100 & 100 & 100 & - \\
\hline \multirow{4}{*}{ Чернівецька } & 410 & 169 & 154 & 137 & 128 & 31,21 \\
\hline & 276 & 22 & 15 & 11 & 10 & 3,6 \\
\hline & 134 & 147 & 139 & 126 & 118 & 88,05 \\
\hline & 32,7 & 87,0 & 90,3 & 92,0 & 92,2 & - \\
\hline
\end{tabular}

Що стосується виробництва баранини в Україні, то, як свідчать статистичні дані, за останні 28 років (табл. 4) виробництво баранини в господарствах усіх категорій зменшилось 3 45,8 (1990 рік) до 14,3 (2018 рік) тисяч тонн у забійній масі, або на 68,78 \% (табл. 4). При цьому в сільськогосподарських підприємствах цей показник зменшився з 29,3 до 0,9, в господарствах населення - 316,5 до 13,4 тисяч тонн, або на 96,93 і 18,78 \% відповідно.

Частка виробленої баранини в господарствах усіх категорій західного регіону України від загального виробництва країни у 1990 році становила 15,5 \%, а в $2018-35,7$ \%, у тому числі: в сільськогосподарських підприємствах - 9,8 і 0,0 \% та в господарствах населення - 5,7 і 35,7 \% відповідно. Серед областей регіону найбільше баранини вироблялось і виробляється на даний час в Закарпатської області, головно в господарствах населення гірської Карпатської зони, де переважає дрібнотоварне виробництво. Таке виробництво, при якому в більшості селянських господарств утримується менше ніж 100 голів овець, як вважає Седіло Г. М. та ін. (Sedilo et al., 2015), не дає можливості увійти на внутрішній і зовнішній ринок, щоб перетворити збиткове вівчарство у прибуткове. Як засвідчують статистичні дані, за останні 10 років рівень збитковості виробництва баранини в сільгосппідприємствах становив 26,7-46,4 \% (Vdovychenko \& Zharuk, 2013). Протягом цих років збитковість вівчарства покривалася за рахунок інших галузей, в основному рослинництва, та дещо державною підтримкою, яка сьогодні відсутня. Такий стан речей, як вважає експерт, не сприяє розвитку галузі вівчарства та потребує державного втручання, завданням якого є збереження галузі через стимулювання збільшення виробництва ягнятини і баранини в сільгосппідприємствах.

Окрім того, як вважають деякі автори (Vdovychenko \& Zharuk, 2013) і ми це підтримуємо, для забезпечення переорієнтації галузі на виробництво баранини необхідно змінити породну структуру поголів'я, збільшивши чисельність овець м'ясововнового та м'ясного напрямів продуктивності. 
Таблиця 4

Виробництво баранини і козлятини в господарствах західного регіону України (у забійній масі, тис. тонн)

\begin{tabular}{|c|c|c|c|c|c|c|}
\hline \multirow{2}{*}{ Країна, область } & \multicolumn{5}{|c|}{ Рік } & \multirow{2}{*}{$\begin{array}{c}2018 \\
\text { в \% до } 1990\end{array}$} \\
\hline & 1990 & 2000 & 2010 & 2015 & 2018 & \\
\hline \multirow{4}{*}{ Україна } & 45,8 & 17,2 & 21,0 & 13,7 & 14,3 & 31,22 \\
\hline & 29,3 & 2,3 & 1,2 & 0,6 & 0,9 & 3,07 \\
\hline & 16,5 & 14,9 & 19,8 & 13,1 & 13,4 & 81,21 \\
\hline & 36,0 & 86,6 & 94,3 & 95,6 & 93,7 & 260,13 \\
\hline \multirow{4}{*}{ Волинська } & 0,7 & 0,2 & 0,2 & 0,1 & 0,2 & 28,57 \\
\hline & 0,5 & - & - & - & - & - \\
\hline & 0,2 & 0,2 & 0,2 & 0,1 & 0,2 & 100,00 \\
\hline & 28,5 & 100,0 & 100,0 & 100,0 & 100,0 & - \\
\hline \multirow{4}{*}{ Закарпатська } & 2,2 & 1,8 & 3,0 & 2,7 & 3,3 & 150,00 \\
\hline & 1,4 & 0,1 & 0,1 & - & - & - \\
\hline & 0,8 & 1,7 & 2,9 & 2,7 & 3,3 & 412,50 \\
\hline & 36,36 & 94,44 & 96,66 & 100,00 & 100,00 & - \\
\hline \multirow{4}{*}{ Івано-Франківська } & 1,1 & 0,5 & 0,3 & 0,4 & 0,4 & 36,36 \\
\hline & 0,5 & - & - & - & - & - \\
\hline & 0,6 & 0,5 & 0,3 & 0,4 & 0,4 & 66,67 \\
\hline & 54,5 & 100,0 & 100,0 & 100,0 & 100,0 & - \\
\hline \multirow{4}{*}{ Львівська } & 0,4 & 0,1 & 0,2 & 0,2 & 0,2 & 50,00 \\
\hline & 0,2 & - & - & - & - & - \\
\hline & 0,2 & 0,1 & 0,2 & 0,2 & 0,2 & 100,00 \\
\hline & 50 & 100,0 & 100,0 & 100,0 & 100,0 & - \\
\hline \multirow{4}{*}{ Рівненська } & 1,0 & 0,1 & 0,1 & 0,2 & 0,2 & 20,00 \\
\hline & 0,8 & - & - & - & - & - \\
\hline & 0,2 & 0,1 & 0,1 & 0,2 & 0,2 & 100,00 \\
\hline & 20 & 100,0 & 100,0 & 100,0 & 100,0 & - \\
\hline \multirow{4}{*}{ Тернопільська } & 0,6 & 0,1 & 0,1 & 0,1 & 0,2 & 33,33 \\
\hline & 0,5 & - & - & - & - & - \\
\hline & 0,1 & 0,1 & 0,1 & 0,1 & 0,2 & 200,00 \\
\hline & 16,7 & 100,0 & 100,0 & 100,0 & 100,0 & - \\
\hline \multirow{4}{*}{ Чернівецька } & 1,1 & 0,7 & 0,4 & 0,5 & 0,6 & 54,54 \\
\hline & 0,6 & 0,1 & - & - & - & - \\
\hline & 0,5 & 0,6 & 0,4 & 0,5 & 0,6 & 120,00 \\
\hline & 45,45 & 85,7 & 100,0 & 100,0 & 100,0 & - \\
\hline
\end{tabular}

\section{Висновки}

Враховуючи сучасний стан галузі вівчарства західного регіону України, для подальшого вдосконалення ведення галузі та його спеціалізації на виробництво високоякісної ягнятини і молодої баранини відповідно до вимог зовнішнього ринку ми підтримуємо рекомендації вчених експертів і вважаємо, що господарствам з розведення овець варто провести такі важливі заходи (Perih et al., 2003; Perih \& Kyryliv, 2013; Vdovychenko \& Zharuk, 2013; Kornienko, 2014; Sedilo et al., 2015; Vdovychenko et al., 2016; 2019):

- генетичне вдосконалення наявних в регіоні м'ясо-вовнових порід і типів методом чистопородного розведення та схрещування місцевого низькопродуктивного маточного поголів'я із плідниками спеціалізованих імпортних м'ясних порід;

- створення нових зональних генотипів тварин м'ясо-вовнового напряму продуктивності з високими продуктивними та відтворювальними якостями, пристосованістю до конкретних кліматичних та виробничих умов;

- удосконалення технології вирощування молодняку, насамперед за рахунок використання дешевих гірських пасовищ полонин та високоврожайних культурних пасовищ;

- впровадження новітніх сучасних промислових технологій утримання і відгодівлі овець для виробництва ягнятини. Враховуючи те, що в 9-місячному віці помісні кросбредні баранчики в середньому досягають 67,8 \% своєї 18-місячної живої маси, то нагул і відгодівлю їх доцільно проводити до 9-місячного віку;

- створення мережі спеціалізованих забійних пунктів, здатних проводити забій овець, оцінку та сортовий розруб туш згідно з вимогами міжнародних стандартів і конкретних споживачів;

• поліпшення ринку збуту виробленої готової продукції;

- підвищення професійних якостей вівчарських кадрів.

Як вважає Ю. В. Вдовиченко (Vdovychenko \& Zharuk, 2013), і ми це підтримуємо, цей процес неможливий без здійснення комплексу заходів у селекційно-племінній роботі; у виробництві продукції, передусім у кормовиробництві та годівлі тварин; науковому забезпеченні нових підходів до питань діагностики, лікування і профілактики захворювань; створенні маркетингової інформаційної системи у вівчар- 
стві; у запровадженні на підприємствах регіону стригального обладнання, обладнання для доїння овець та кіз, засобів штучного осіменіння вівцематок.

\section{References}

Derzhavna sluzhba statystyky Ukrainy (2019). State Statistics Service of Ukraine. Tvarynnytstvo Ukrainy 2018. Animal production of Ukraine 2018. Statystychnyi zbirnyk. Statistical yearbook. Kyiv (in Ukrainian).

Havryliak, V., Stapay, P., \& Tkachuk, V. (2018). The content and composition of the longissimus muscle proteins in the lambs of different ages under the intensive fattening. Scientific Messenger of LNU of Veterinary Medicine and Biotechnologies. Series: Agricultural Sciences, 20(89), 52-55. doi: 10.32718/nvlvet8909.

Holovach, M. I. (1996). Biolohichni osoblyvosti ta hospodarski pokaznyky pomisnykh ovets prekos $\mathrm{X}$ latviiska temnoholova $\mathrm{i}$ prekos $\mathrm{X}$ romni-marsh $\mathrm{v}$ umovakh Prykarpattia. Avtoref. dys.... kand s.-h. nauk. Lviv (in Ukrainian).

Kornienko, H. V. (2014). Development trends of sheep breeding: Ukraine and international experience. Ahrarnyi visnyk Prychornomoria. Ekonomichni nauky, 75, 54-64.

Melnychuk, V., \& Yuskiv, I. (2018). Studying of disinvasion action of the disinfectant Virosan for eggs Nematodes genus Trichuris parasitizing in sheep. Scientific Messenger of LNU of Veterinary Medicine and Biotechnologies. Series: Veterinary Sciences, 20(88), 16-23. doi: 10.32718/nvlvet8803.

Perih, D. P., \& Kyryliv, Ya. I. (2013). Problemy rozvytku vivcharstva $\mathrm{v}$ umovakh zakhidnoho rehionu Ukrainy ta shliakhy yikh vyrishennia. Nauk. visnyk Dnipropetrovskoho derzhavnoho ahrarnoho universytetu, 2, 125-127 (in Ukrainian).

Perih, D. P., Hil, L. H., \& Kyryliv, Ya. I. (2003). Rozvytok populiatsii ovets karpatskoi zony Ukrainy. Nauk. visnyk LNAVM im. S. Z. Hzhytskoho, 5(3), 182-187 (in Ukrainian).

Petryshyn, M. A., Haivanovych, S. I., \& Yatskevych, Yu. O. (1995). Yakist vovny pered karpatskoho i zakarpatskoho vnutripordnykh typiv. Zb. Vivcharstvo. K.: Ahrarna nauka, 28, 53-56 (in Ukrainian).

Sando, C., Enser, M. E., Campo, M. M., Nute, G. R., Maria, G., Sierra, I., \& Wood, I. D. (2000). Fatty acid compo-sition and sensory characteristics of lamb carcasses from Britain and Spain. Meat Science, 54, 339-346. doi: 10.1016/S0309-1740(99)00108-4.

Sedilo, H. M., Vovk, S. O., \& Petryshyn, M. A. (2015). Suchasnyi stan i osnovni napriamy rozvytku vivcharstva v Karpatskomu rehioni. Visnyk Dnipropetrovskoho derzhavnoho ahrarno-ekonomichnoho universytetu, 3, 107-111 (in Ukrainian).

Sinclair, L. L. (2007). Nutritional manipulation of the fatty acid composition of sheep meat: a review. Aqr. Sci., 145(5), 419-434. doi: 10.1017/S0021859607007186.

Sokol, O. (2003) Osnovni tendentsii rozvytku vivcharstva v Ukraini i sviti. Animal production of Ukraine, 4, 4-7 (in Ukrainian).

Terek, V. I., Perih, D. P., \& Hil, L. H. (1999). Problemy konsolidatsii ovets ukrainskoi hirskokarpatskoi porody. Nauk visnyk LDAVM im. S. Z. Hzhytskoho, 3(2), 206-208 (in Ukrainian).

Tkachuk, V., Stapay, P., \& Motko, N. (2018). The influence of seasonal factors on the content of keratoses, free internal lipids, and physical characteristics of sheep wool. Scientific Messenger of LNU of Veterinary Medicine and Biotechnologies. Series: Agricultural Sciences, 20(84), 44-48. doi: 10.15421/nvlvet8408.

Vdovychenko, Yu. V., \& Zharuk, P. H. (2013). Stan ta perspektyvy rozvytku haluzi vivcharstva Ukrainy. Visnyk Dnipropetrovskoho derzhavoho ahrarnoho universytetu, 1, 136-138 (in Ukrainian).

Vdovychenko, Yu. V., Iovenko, V. M., Zharuk, P. H., Kudryk, N. A., \& Zharuk, L. V. (2016). Stan naukovoho zabezpechennia haluzi vivcharstva. Naukovoteoretychnyi fakhovyi zhurnal "Naukovyi visnyk "Askaniia-Nova". Instytut tvarynnytstva stepovykh raioniv imeni M. F. Ivanova "Askaniia-Nova". Natsionalnyi naukovyi selektsiino-henetychnyi tsentr z vivcharstva. Nova Kakhovka "PYEL", 9, 3-16 (in Ukrainian).

Vdovychenko, Yu. V., Zharuk, P. H., \& Zharuk, L. V. (2019). Prohramni zasady stvorennia miasnoho vivcharstva Ukrainy. Fakhovyi tematychnyi naukovyi zbirnyk Vivcharstvo ta kozivnytstvo. Instytut tvarynnytstva stepovykh raioniv imeni M. F. Ivanova "Askaniia-Nova" Natsionalnyi naukovyi selektsiinohenetychnyi tsentr $\mathrm{z}$ vivcharstva. Nova Kakhovka "PYEL", 4, 6-17 (in Ukrainian). 